\title{
No More Liaisons: Collection Management Strategies in Hard Times
}

\section{Karen Jensen}

To cite this article: Karen Jensen (2017): No More Liaisons: Collection Management Strategies in Hard Times, Collection Management, DOI: 10.1080/01462679.2016.1263812

To link to this article: $\mathrm{http}: / / d x . d o i . o r g / 10.1080 / 01462679.2016 .1263812$

曲 Published online: 17 Jan 2017.

Submit your article to this journal $\asymp$

Џll Article views: 105

Q View related articles ¿

View Crossmark data $\longleftarrow$ 


\title{
No More Liaisons: Collection Management Strategies in Hard Times
}

\author{
Karen Jensen \\ University of Alaska Fairbanks Rasmuson Library, Fairbanks, Alaska
}

\begin{abstract}
Collection development in medium to large academic libraries typically involves multiple subject librarians or "liaisons." The University of Alaska Fairbanks (UAF) Libraries have lost significant numbers of personnel in the last four years due to attrition and retirements, including most of the professional liaison librarians whose positions will not be replaced in the foreseeable future. In addition to this challenge, collection budgets have been severely reduced due to the State of Alaska's ongoing budget crisis, necessitating large cancellation projects. This article examines UAF Libraries' collection strategies used to sustain a research-intensive collection without liaisons and with a drastically reduced budget.
\end{abstract}

\section{KEYWORDS}

Academic libraries; budget

cuts; collection

management; liaison

librarians

\section{Introduction}

In recent years, the University of Alaska Fairbanks (UAF) Libraries have had to make major modifications to the ways library materials are selected, maintained, and developed, due to budget cuts and the elimination of our liaison librarian program. The greatest impact on library operations has been the reduction in professional librarians through attrition and retirement. Cutting these salary lines has saved the library from layoffs and even more drastic collection cuts, but not without impact. This paper will describe the techniques the UAF Libraries are using to sustain library collections, despite the dim economic outlook. Included is an examination of patron satisfaction with library collections and services, based on recent campus-wide surveys. Finally, the conclusion outlines a proposal for a future, smaller yet effective library institution, looking beyond the immediate budget crisis and distilling the essence of what our patrons truly want and need from the library.

\section{Budget situation}

During the U.S. financial crisis and recession of 2007 and 2008, when libraries across the country were hit with massive budget cuts and layoffs, the State of

CONTACT Karen Jensen kljensen@alaska.edu U University of Alaska Fairbanks Rasmuson Library, 310 Tanana Loop, Fairbanks, AK 99775.

Published with license by Taylor \& Francis. @ 2017 Karen Jensen 
Alaska had an enviable budget, thanks to its reliance on the price of oil, which in July of 2008 was a record-breaking $\$ 147.02$ a barrel (BBC 2008). With adequate state funding, a variety of direct grants, and ample research overhead dollars, the UAF Libraries were for many years able to provide excellent support for collection development (the library gets an enviable $4.7 \%$ share of the institutional "tax" on grants for facilities and administrative costs). The libraries could then afford a wide range of subscriptions, substantial annual one-time purchases, and an active monograph approval and standing order program and had a full professional staffing load. Fourteen liaisons covered all academic departments, distance patrons, and a community college. As the financial crisis in the lower forty-eight states continued, Alaskans were largely unaffected. Vendor visits were frequent, and the library's liaison team conducted multiple product trials, analyzed heavy use areas for possible additional materials (Jensen 2012), and kept large wish lists for end-of-year spending.

With the recent fall of oil prices starting in June 2014, Alaska's state economy is now far worse than what the U.S. experienced in the financial crisis of 2007 and 2008 (Krauss 2016). While the lower forty-eight states are well into recovery, Alaska now suffers the result of lack of state government planning for long-predicted hard times. With oil at the time of this writing priced less than \$50 a barrel (NASDAQ 2016), the Alaska state government and hence the University of Alaska are now undergoing a severe budget crisis, considered by analysts to be the "worst economic disaster since statehood" (Erickson and Barker 2015). For the last four consecutive years, the UAF Libraries have seen major annual budget cuts and have reduced staffing by about one-third in total, with only four professional, tenure-track faculty librarians remaining on staff.

Teaching and service loads for librarians have vastly increased, leaving no time for traditional liaison activities, and the library has very little funding to support traditional subscriptions and purchases. Hits to collections are such that many resources once considered essential for any research institution have been eliminated, as well as anything at all with minimal use. The crisis is sufficiently dire that a branch science library was closed in order to eliminate two full-time staff and one student position, despite that branch being in the research-intensive area of campus.

The current less-than-ideal situation has required implementing alternative methods for collection development, as well as for other library services that once relied on liaisons. Traditional liaison functions, including building relationships with campus faculty, course-integrated library instruction sessions, reference services, and materials selection have all been modified, minimized, transferred to classified staff, or eliminated. Out the door are any thoughts of standard or best practices, benchmarking with peers, deep collection assessment, and the traditional liaison model; the library simply no longer has the personnel to accomplish these tasks in the ways standard to academic libraries. Instead, online tutorials now substitute for one-shot instruction sessions, reference is staffed with non-librarians, and collections are managed without departmental liaisons. But as our recent patron surveys 
Faculty satisfaction with library and collections

\begin{tabular}{|c|c|c|c|}
\hline $\begin{array}{c}\text { Survey } \\
\text { year }\end{array}$ & $\begin{array}{c}\text { Very satisfied or satisfied } \\
\text { with the library }\end{array}$ & \multicolumn{2}{|c|}{$\begin{array}{c}\text { Very satisfied or satisfied } \\
\text { with library collections }\end{array}$} \\
\hline 2007 & $90 \%$ & \multicolumn{2}{|c|}{$84 \%$} \\
\hline 2010 & $94 \%$ & \multicolumn{2}{|c|}{$91 \%$} \\
\hline 2015 & $91 \%$ & \multicolumn{2}{|c|}{$88 \%$} \\
$\begin{array}{c}\text { Very satisfied or } \\
\text { satisfied with } \\
\text { book collections }\end{array}$ & $\begin{array}{c}84 \% \\
\text { Very satisfied } \\
\text { or satisfied } \\
\text { with journals } \\
\text { collections }\end{array}$ \\
\hline
\end{tabular}

Figure 1. Triennial campus-wide surveys show fairly consistent faculty satisfaction with library collections.

have shown, the elimination of the liaison model of collection development have not greatly affected patron satisfaction. (See Figure 1.) As the library strategizes for a new future, our experience without liaisons is offering a very different vision of how the academic library might look.

\section{Literature review}

Many academic libraries have undergone budget crises, and the library literature abounds with their stories, too voluminous to review more than a few here. Scouring the stories in hopes of finding ways to mitigate the budget shortage and lack of collection personnel, we found plenty. Most recently, a vendor industry report notes several ways libraries are managing budget shortfalls, through use analysis, breaking up big journal packages, and focusing spending on electronic rather than print resources (Collins 2012). Mary Ann Prottsman of the University of Southern California Health Sciences Libraries describes the ways her institution has alleviated funding shortages using cooperative purchasing networks, negotiation with vendors to reduce prices, and doing patron needs assessment to guide cancellations (Prottsman 2011). The University of California, Berkeley managed to find donor support to sustain collections during challenging budgetary times (Howard 2009).

Mary Ann Trail writes about the effect of multiple budget cuts on her library. She describes the public relations difficulty libraries can encounter during budget crises and emphasizes the need for well-presented use and cost data to justify decisions, as well as good relationships between faculty and librarians to prevent "public attacks" (Trail 2013: 219). Her experience speaks to the importance of connections between the library and its patrons, which are usually maintained through traditional liaison programs staffed by librarians. Perhaps the perceived impact of those patron connections with librarians is the primary reason that most libraries maintained their liaison programs throughout the 2008 financial crisis, despite the high cost of professional personnel. Regardless of their real or perceived importance, the UAF Libraries were simply unable to support multiple liaison positions, given the dire budget situation. 
The literature on liaison programs is likewise substantial, for example, covering expected duties, varying roles, performance evaluations, and perception of liaison programs by patrons. Jonathan Miller describes the massive amount of literature on library liaison programs and notes that few studies really analyze their effectiveness or look at the actual performance of individual liaisons (outcomes). Miller's article focuses on methods of evaluating liaison performance but never really questions the assumption that the liaison model is the most effective way to garner patron support or satisfaction or build better collections. He does note the significant effort required in this model, stating that "building partnerships with faculty ... is one of the most challenging elements of academic librarianship" (Miller 2014: 493). What neither he nor any of the other authors ask is whether the effort and cost required to maintain a quality liaison program is justified by the results. Are academic library patrons clamoring for partnerships with librarians? Miller also quotes a very old article on liaison work by Laurence Miller stating that the library liaison program is a "vulnerable" method (Miller 1977) in which "partnerships must be constantly nurtured and developed" (Miller 2014: 493). Julie Arendt and Megan Lotts, in a 2012 opinion survey of both liaisons and their patrons, show that the services valued and ranked highly by liaisons are not the same as those valued and ranked higher by their faculty (Arendt and Lotts 2012). More studies of this type in which patron views of liaisons are analyzed might help to clarify whether liaison work is perceived as valuable by those served.

James Thull and Mary Anne Hansen, in their 2009 summary of academic liaison programs, state that "identifying the user's needs ... is the overall primary goal of liaison work" (Thull and Hansen 2009: 530). They also claim that "the benefits of liaison activities for everyone involved are clear," but do not substantiate such an assumption (Thull and Hansen 2009: 532). A 2011 article by Carolyn Carpan concurs with Thull and Hansen and reiterates that the primary purpose of liaisons is "to provide personal communication with faculty about library services, information literacy and instruction, and collections" (Carpan 2011: 104). Are library liaison programs really the most cost-effective way to promote services and assess user needs; do they really work? The many articles on liaison programs do not provide evidence to that effect, nor are the benefits necessarily clear, although many authors express the opinion that they are. Other service institutions promote their offerings and do customer research without such personnel-intensive programs. What is distinctly different about libraries that makes the liaison model so necessary?

In the Association of Research Libraries SPEC Kit 349, Rebecca Miller and Lauren Pressley summarize the ways liaison programs have changed around the country in recent years and throughout their executive summary describe the significant effort needed to make these programs effective. They describe many libraries decreasing the other service requirements for library liaisons, including responsibility for collection development, due to the huge amount of time required for making contacts with faculty (Miller and Pressley 2015). They conclude-without offering supporting evidence other than liaison opinions-that "the benefits of these 
programs remain clear" (Miller and Pressley 2015: 18), but those benefits are not concretely described or objectively measured. Anne Kenney in a 2015 article on developments in liaison programs states that "most efforts to quantify liaison activity are library-centered and focus on what the liaison is doing rather than what effects those activities have had"; she then describes some ongoing efforts to try to show evidence for the value of liaison work (Kenney 2015: 388).

Harder to find are articles that describe effective collection development or outreach efforts in academic libraries that use models other than liaison programs, as the UAF Libraries have been forced to do. In a 2014 article, Morris and Currie describe their library moving from an older style liaison model with multiple subject librarians to a smaller collection development team approach, taking advantage of some of the same technologies the UAF Libraries are using. They asked former subject librarians to complete a questionnaire with content aimed at helping the new smaller team make monograph selections and used patron-driven acquisition (PDA) to spend out the budget (Morris and Currie 2014). However, in their conclusion, they note that the changes occurred only shortly before press time and, in describing the changes, observe that deep subject content knowledge has been lost.

In the absence of liaisons due to budget reductions, how are other libraries managing collections? What do remaining librarians do to create rapport with faculty and students; how do they become familiar with subject areas and ensure relevant collection resources? What other methods of assessing patron needs are used? How are resource cuts managed? Without any guidance from other libraries' experience in cutting liaison programs, and given the impossibility of creating new positions at the present time, the UAF Libraries had no choice but to move ahead in finding other ways to accomplish those goals. While we did not set out to eliminate liaisons, the budget situation made it happen and the library must continue to provide useful services and collections.

\section{Alternative techniques for collection management}

As described throughout the library literature, the liaison model is the predominant technique for building and maintaining library collections, using multiple professional librarians to build collections that satisfy patrons. The unproven assumptions of this model are many, including that the subject specialist librarian will make better book selections, that the liaison will learn thoroughly about the curriculum and research in their respective subject areas, that librarians have well-suited personalities for building relationships with faculty, that those relationships will translate into better and more heavily used collections and services, and that having established rapport with patrons will increase support for the library, especially in difficult times.

Despite the many articles about liaison programs, hard evidence that liaison programs meet any or all of these outcomes is scant. Nonetheless, the UAF Libraries also relied heavily on a liaison program until just recently, when most of our librarians retired or resigned, and the funds for hiring replacements disappeared. Each 
librarian had covered several related disciplines and gained familiarity with jargon, publication practices, course content, and research interests in the field. The liaisons provided course-integrated instruction, met new faculty, and provided orientations for new students in the field. Each librarian also selected subjects in a monograph approval plan and recommended journals or databases for trial or subscription. What would happen without them?

\section{Impact on monographs collection}

Since the gradual disappearance of most of our liaisons starting five years ago, the collection development department has had to change a number of practices and procedures. The greatest changes involved a shift in the selection methods of monographs, once tied directly to liaison work.

One of the first tasks in changing our monograph procedures was to assess individual liaison book selections to see how well titles selected by liaisons were used. This assessment involved compiling lists of recent purchases by Library of Congress classification and running annual circulation reports on those titles, one and two years after addition to the library catalog. There was significant variance among different liaisons' subjects, but in no subject did more than $50 \%$ of the liaison-selected titles circulate in the first two years of ownership. Some subjects showed far less use, such as only $10 \%$ circulation for one subject (engineering). Since only one-third of the entire owned print collection had ever circulated, it seems that liaison selection of monographs was not time- or cost-effective. In a world of some $64,000+$ academic books published annually according to YBP's 2015 Annual Book Price Update (YBP 2015), and in which fewer library books circulate each year, title-by-title selection is no longer time well spent, and without liaisons several other strategies have had to be substituted.

The second change involved evaluation and subsequent overhaul of the library's approval plan. Monograph use in our libraries has been declining rapidly throughout the last decade, matching the trend across other academic libraries, as shown by Association of Research Libraries statistics (Association of Research Libraries 2014). A significant reduction in the monograph budget was therefore appropriate, rather than continuing to spend scarce funds on items that might never be used. At first the approval plan was cut entirely, then some subjects were re-added, such as our unique collection plan in Arctic, Alaska, and polar research topics, where the goal is a comprehensive collection. Also, since few books are published annually in these topics, the targeted approval system works well. We also added an approval plan for major award-winning titles particularly in the sciences. A quick look at our circulation statistics for scientific award titles for the last several years verified that these titles were much more heavily used than other recently acquired titles selected by liaisons.

The next change the library implemented was a PDA e-book program, allowing deep and broad access to hundreds of thousands of academic books, on the shortterm loan pay-per-use model, with title purchase on the fourth use. Examining the 
use statistics and breadth of titles accessed, the program was a phenomenal success, giving patrons the option to use thousands of books that would likely not have been selected by any liaison yet were still within the scope of our selection criteria. The e-book PDA program resulted in 962 e-books permanently added to the library's collection, mostly in the sciences and engineering. Many more titles were used only once, representing a large number of books that, had they been added in print to our space-limited shelves, would likely serve the future for dust collecting, as well as costing significantly more at the outset than the short-term loan price. In 2014, a slight modification was required, due to some publishers removing titles from aggregator programs or vastly increasing single-use (short-term loan) prices, forcing the library to remove or moderate access to those publishers. However, the e-book PDA program still complements traditional collecting, especially supporting those "long tail" titles, and ensures better breadth and depth of available library books than could ever have occurred through liaison print selection alone.

Based on the success of the e-book program, the library added patron-driven print purchasing as well in the fall of 2015, which has transferred even more of the title selection effort from liaisons to patrons. This program, using a cooperative workflow among Interlibrary Loan, Technical Services, and Collection Development departments, is still under development, but early results promise to increase monograph collection depth in specific research areas currently underrepresented in the library's collections. Faculty and student response to the patron-driven print book program has been positive and has actually encouraged more faculty to make purchase recommendations through the already established recommendation form located on the library website. Formal assessment of patron satisfaction with this program and analysis of the future use of these titles will be necessary to offer a fair comparison with librarian-selected materials.

Finally, the library gave new campus faculty the opportunity to contribute to our print monograph collections directly by allotting each member a portion of the monograph budget for their own selections and guiding them toward selection tools. Of the monograph program changes implemented, this option has been the least rewarding in building the print book collection; only a few new faculty took advantage in making title selections and the program has subsequently been dropped due to lack of interest.

One of the seemingly odd results of reducing the number of liaisons and also reducing the monograph budget significantly is that the few individual subject book funds remaining are still often not fully expended by deadline dates. As Morris and Currie point out, it actually takes more time to select monographs when only a few can be made, so that the selector ensures getting one that will be used (Morris and Currie 2014: 104).

Some librarians might view the changes to monograph selection as job threats, and indeed these methods require fewer professional personnel to manage, exactly the reason we needed to implement the changes. The oversight of the programs, however, still requires librarian expertise to ensure collection adequacy as well as long-term viability, especially in the electronic book area where publishers 
frequently remove titles. Librarians will also be required to stay current with and manage new technologies that make more materials available to patrons. However, these tools have allowed the UAF Libraries to function reasonably well with fewer liaisons directly involved in the monograph program.

Other aspects of monograph collection management are more challenging to accomplish without knowledgeable liaisons, such as continual evaluation of the collections in order to maintain currency with curriculum and research changes, review of damaged or worn materials, and updating editions-tasks that simply cannot be automated or turned over to patrons. Susan Herzog in a 2004 article on recent changes to collection development practices states that "all other areas of the collection should be reviewed every three to five years" (Herzog 2004: 152). Obviously, such a recommendation necessarily relies on librarians who have familiarity with research needs in order to ensure the retention of essential but rarely used titles.

\section{Assessment: What do the researchers think?}

Liaison relationships with department faculty and graduate students have long served as a direct feedback mechanism, allowing for the gathering of opinions and prompt response to needs. In the absence of those liaisons, however, it becomes more challenging and even more important to do regular assessment to ensure that the libraries are meeting expectations and needs and that there are no major content gaps. The UAF Libraries have conducted campus-wide user surveys in 2007, 2010, and 2015 and the data provided in these surveys have assisted with many collection development decisions. The early surveys also serve as a baseline for comparing patron satisfaction before and after elimination of the liaison program and budget cuts.

Beginning in 2007 and prior to budget cuts and loss of positions, the UAF Libraries created an assessment program consisting of triennial campus-wide surveys, modeling the initial survey and the assessment cycle after the program created at the University of Washington libraries (University of Washington Libraries Assessment 2016). The survey queries patrons about all services and collections, and response rates have varied: $25 \%$ of faculty in $2007,31 \%$ in 2010 , and $12 \%$ in 2015 . In the most recent survey in 2015, questions had to be modified and the survey shortened in order to minimize survey fatigue due to multiple campus departments implementing surveys simultaneously. The changes resulted in new and more detailed collection questions and fewer questions overall. In 2015 the survey asked specifically about satisfaction with journals, books, e-books, databases, media, and special collections. While these data will more acutely gauge future response to collection changes, the question changes challenge longitudinal comparisons.

The most recent campus-wide survey, distributed in fall of 2015, occurred at a time when most academic departments no longer had a liaison librarian. From 2010, when the library had fourteen liaisons (thirteen of whom were professional librarians), to 2015, when seven remained (including four professional librarians), 


\begin{tabular}{|c|c|c|c|c|}
\hline & $\begin{array}{c}\text { Very } \\
\text { satisfied } \\
(\%)\end{array}$ & $\begin{array}{c}\text { Satisfied } \\
\text { (\%) }\end{array}$ & $\begin{array}{c}\text { Dissatisfied } \\
(\%)\end{array}$ & $\begin{array}{c}\text { Very } \\
\text { dissatisfied } \\
(\%)\end{array}$ \\
\hline Print books & 18.6 & 70.1 & 10.3 & 1.0 \\
\hline E-books & 11.4 & 73.4 & 15.2 & 0.0 \\
\hline Journals (print and online) & 18.8 & 66.1 & 12.5 & 2.7 \\
\hline Alaska and Polar Regions & 26.2 & 72.1 & 1.6 & 0.0 \\
\hline Databases & 21.1 & 71.1 & 7.9 & 0.0 \\
\hline Videos/DVDs & 25.4 & 66.1 & 6.8 & 1.7 \\
\hline $\begin{array}{l}\text { ScholarWorks@UA } \\
\text { institutional repository }\end{array}$ & 19.4 & 67.7 & 9.7 & 3.2 \\
\hline Other collections & 31.3 & 68.8 & 0.0 & 0.0 \\
\hline
\end{tabular}

Figure 2. The most recent campus-wide survey breaks down collection satisfaction by format.

the survey results for faculty show no significant decline in reports of total satisfaction with the library, the book collections, or journal access. (See Figures 2 and 3.) There were no comments or suggestions in any of the surveys that indicated any dissatisfaction with liaisons specifically and no mention of them generally. It appears, then, that the decline of the liaison program was little noticed by the faculty. Followup assessment may be in order in a few years to determine whether the continued decline in library personnel numbers since 2015 and the changes made in collection development methods affect patron perceptions long-term. The future 2018 survey results, with questions consistent with the 2015 survey, will perhaps be revealing in demonstrating whether the absence of department liaisons has affected quality of collections and therefore patron satisfaction.

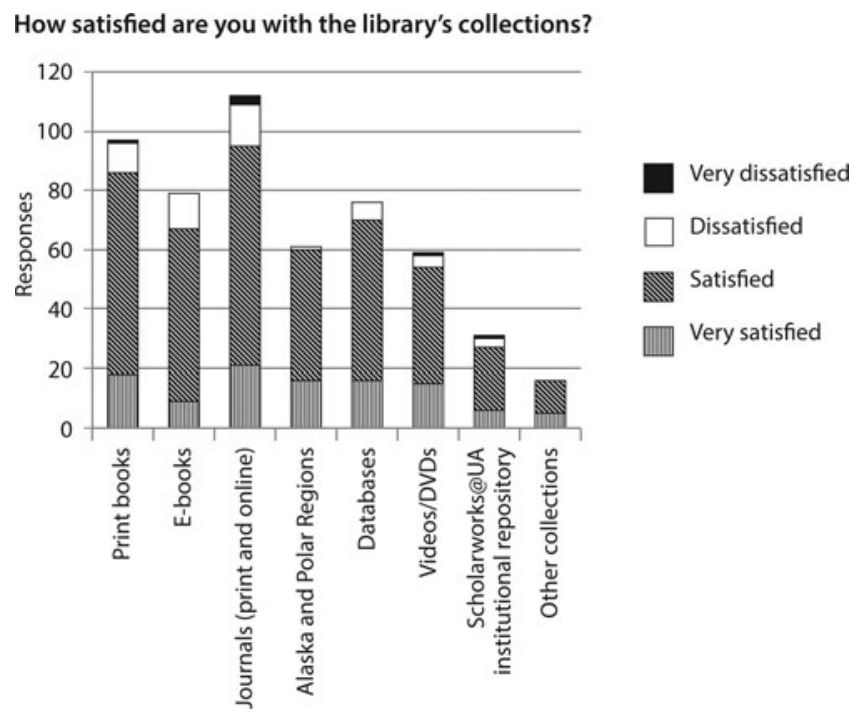

Figure 3. Data from the 2015 surveys will be compared with future surveys, analyzing specific types of library materials. 


\section{Discussion}

While there seems to be little impact on patron satisfaction with monographs, UAF library liaisons in past years typically were also highly involved in serials decisions. Using subject knowledge and familiarity with academic department specialties, liaisons added new journals to our subscription wish list and assisted in prioritization of titles. Liaisons also reviewed journal subscriptions annually, examined use statistics, and conducted citation analyses and syllabi audits. Despite the disappearance of most of the liaisons, all of these activities are still necessary, but unlike the case of monographs, fewer alternatives are provided by new technologies or acquisition programs. Assessment of such activities is also significantly more challenging given the vast number of journals made available through packages, rather than title-by-title selection. The "big deals," in which the library gains access to a publisher's entire range of journals for a set fee in addition to core subscriptions, have made it easy to manage serials without subject experts, but as the budget crisis worsens, some of those large packages will be canceled. Without liaisons, and subsequently less direct and less frequent contact between the library and campus faculty, it is more challenging to obtain faculty feedback about individual journal titles or small, lesser-used packages. Because journals are the core of scientific research, patron dissatisfaction will undoubtedly rise as the cutbacks occur.

The lack of subject knowledge at the library becomes a significant problem when making individual journal cancellations. Basing cancellation decisions on cost per use, without a deeper understanding of the needs of department faculty and without a background in the discipline, is fraught with potential for error. Mere analysis of figures does not guarantee a good final decision, as a recent case in our libraries demonstrated. For example, when use figures were analyzed recently a decision was made to cancel a journal based on a COUNTER JR1 report showing zero use for several years in a row. However, the journal title in question was fundamental for one small research program in particular. A good subject liaison would have been familiar with the ongoing research area as well as the journal title and would have surmised that the statistic was a discrepancy and perhaps consulted individual faculty directly. With that consultation, the liaison would have learned that in fact the journal is heavily used and the vendor usage information was flawed. In this case, a cancellation was made and the error not discovered until a current journal article was needed but unavailable, opening a dialogue between the library and affected faculty.

Some services provided by knowledgeable librarians simply cannot be replaced through automation. We have found no serials management alternative to liaison expertise since our personnel reduction, although pay-per-view options have been considered. How effective are liaisons at selecting and managing serials, and what other possibilities exist? Both questions may be good candidates for future research, analysis, and experimentation. 


\section{Conclusions}

Until the budget situation improves, which could be a number of years in the future, the UAF Libraries are forced to continue without liaisons in place. Most experts believe that the price of oil will rebound; the major oil company BP predicts it will surpass $\$ 100$ again and with that rising price so, too, there will be more funds for the University of Alaska (Macalister 2016). If and when such an event becomes reality, what will the optimal staffing allocation look like for the UAF Libraries? What might be proposed as our new ideal, rather than returning to previous methods and staffing levels for managing collections? If we are mostly successful at maintaining collections without liaisons, how might professional librarians' skills be better utilized? There are still some collection management activities and tasks not being attended to due to the absence of liaisons. How might those collection needs be addressed under a different model, other than a liaison program?

It seems clear from our experience of the last five years that our library patrons do not miss having close contacts with liaison librarians. While our triennial surveys contain occasional negative remarks about specific areas of the book and journal collections, the rate of negative comments is quite low and has not risen since the liaison program disbanded. Patron-driven selection models for monographs, and increasingly for journals, that emphasize speed of access as well as breadth and depth of content seem to suffice for the moment to ensure that needed materials are available. It seems likely that there will continue to be additional technological developments as well that allow for more need-based access, rather than libraries paying to amass large and largely unused collection materials selected by liaisons. The library is unlikely to return to a full complement of liaisons, but perhaps instead will implement a model in which librarians (not liaisons) have primary duties such as scholarly publishing, public relations, institutional repository management, or other special programs but will also have academic subject expertise to assist with a limited set of collection-related functions, such as preservation, collection analysis, cancellations, and specialized in-depth reference as needed. Job descriptions under this approach might require some subject expertise but at a more general level, i.e., social sciences instead of psychology, or in some special cases be more in-depth for the most highintensity research areas.

The future of our library is of course uncertain, but what is certain is that this organization will likely remain smaller than it was prior to budget cuts and job roles will continue to change as we work to streamline and be more efficient than before, yet just as effective in serving our patrons.

\section{References}

Arendt, Julie, and Megan Lotts. 2012. "What Liaisons Say About Themselves and What Faculty Say About Their Liaisons, a U.S. Survey." Portal 12 (2):155-177.

Association of Research Libraries. 2014. "Statistical Trends." Service Trends in ARL Libraries 1991-2012. Washington: Association of Research Libraries. 
BBC. 2008. "Oil hits new high on Iran fears." BBC News Online, July 11. Accessed August 18, 2016. http://news.bbc.co.uk/2/hi/business/7501939.stm.

Carpan, Carolyn. 2011. “The Importance of Library Liaison Programs.” College \& Undergraduate Libraries 18 (1):104-110.

Collins, Tim. 2012. "The Current Budget Environment and Its Impact on Libraries, Publishers and Vendors." Journal of Library Administration 52 (1):18-35.

Erickson, Gregg, and Milt Barker. 2015. The Great Alaska Recession [report by consultants Erickson and Associates], April 12. Accessed December 15, 2016. http://www.alaskapublic.org/wpcontent/uploads/2015/06/Erickson150412-The-Great-Alaska-Recession.pdf.

Herzog, Susan. 2004. "Collection Development Challenges for the 21st Century Academic Librarian." The Acquisitions Librarian 16 (31-32):149-162.

Howard, Jennifer. 2009. "Libraries Innovate to Counter Cuts." Chronicle of Higher Education 56 (14):A1-A9.

Jensen, Karen 2012. "Data-Driven Decisions for Library Liaisons: Exploring Strategies for Effectively Managing Diminishing Monograph Collections." Collection Management 37 (1):9-22.

Kenney, Anne R. 2015. "From Engaging Liaison Librarians to Engaging Communities." College and Research Libraries 76 (3):386-391.

Krauss, Clifford. 2016. “Oil Prices: What's Behind the Drop? Simple Economics." New York Times, July 27. Accessed August 18, 2016. http://www.nytimes.com/interactive/2016/business/ energy-environment/oil-prices.html?_r=1.

Macalister, Terry. 2016. "BP Upbeat About Oil Industry and Expects Prices Back at \$100." The Guardian, February 10. Accessed December 15, 2016. https://www.theguardian. com/business/2016/feb/10/bp-upbeat-about-oil-industry-with-prices-back-at-100-dollars.

Miller, Jonathan. 2014. "A Method for Evaluating Library Liaison Activities in Small Academic Libraries." Journal of Library Administration 54 (6):483-500.

Miller, Laurence. 1977. "Liaison Work in the Academic Library." RQ 16 (3):213-215.

Miller, Rebecca K., and Lauren Pressley. 2015. SPEC Kit 349: Evolution of Library Liaisons. Washington, DC: Association of Research Libraries.

Morris, Sara E., and Lea Currie. 2014. "Remember Me? Content Development in a User-Centered Services Library." Collection Management 39 (2-3):96-109.

NASDAQ. 2016. Crude Oil, End of Day Commodity Futures Price Quotes for Crude Oil WTI (NYMEX). NASDAQ. Accessed August 18, 2016. http://www.nasdaq.com/markets/crudeoil.aspx.

Prottsman, Mary Fran. 2011. "Communication and Collaboration: Collection Development in Challenging Economic Times." Journal of Electronic Resources in Medical Libraries 8 (2):107116.

Thull, James, and Mary Anne Hansen. 2009. "Academic Library Liaison Programs in US Libraries: Methods and Benefits." New Library World 110 (11/12):529-540.

Trail, Mary Ann. 2013. "Evolving With the Faculty to Face Library Budget Cuts." Serials Librarian 65 (2):213-220.

University of Washington Libraries Assessment. 2016. Seattle: University of Washington Libraries. Accessed October 17, 2016. http://www.lib.washington.edu/assessment/.

YBP. 2015. Annual Book Price Update. Contoocook, NH: YBP. 